\title{
Experimental dimensions and precision in trials with millet and showy rattlebox
}

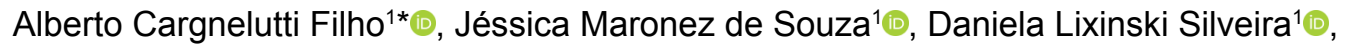

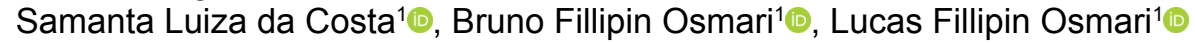

\footnotetext{
1 Universidade Federal de Santa Maria, Santa Maria, RS, Brasil. E-mail: alberto.cargnelutti.filho@gmail.com; jessica_maronez@hotmail.com; danilisi@hotmail.com; samyldc09@hotmail.com; brunoosmari11@gmail.com; lucasfosmari@gmail.com
}

ABSTRACT: The objective of this study was to determine the optimal plot size to evaluate the mass of fresh matter in millet (Pennisetum glaucum L.) and showy rattlebox (Crotalaria spectabilis Roth.), in scenarios formed by combinations of treatment numbers, repetitions numbers, and levels of experimental precision. Fifteen uniformity trials with millet and showy rattlebox, in single or intercropping, were carried out. The mass of fresh matter was evaluated in 540 basic experimental units (BEU) of $1 \times$ $1 \mathrm{~m}$ (15 trials $\times 36 \mathrm{BEU}$ per trial). The heterogeneity index of Smith (1938) was estimated. The plot size was determined by the method of Hatheway (1961) in scenarios formed by combinations of $i$ treatments $(i=5,10,15,20$, and 25$), r$ repetitions $(r=3$, $4,5,6,7,8,9$, and 10), and d precision levels ( $d=4,5,6,7,8,9,10,11,12,13,14,15,16,17,18,19$, and 20\%). To evaluate the mass of fresh matter of millet and showy rattlebox, in single or intercropping, with 5 to 25 treatments and with five repetitions, plots of $10 \mathrm{~m}^{2}$ of useful area are sufficient for differences between treatments of $9 \%$ of the overall average of the experiment to be considered significant at 0.05 probability.

Key words: Crotalaria spectabilis Roth.; optimal plot size; Pennisetum glaucum L.; repetitions numbers; soil cover crop

\section{Dimensionamentos experimentais e a precisão em ensaios com milheto e crotalária spectabilis}

RESUMO: O objetivo deste trabalho foi determinar o tamanho ótimo de parcela para avaliar a massa de matéria fresca de milheto (Pennisetum glaucum L.) e de crotalária spectabilis (Crotalaria spectabilis Roth.) em cenários formados por combinações de números de tratamentos, números de repetições e níveis de precisão experimental. Foram conduzidos 15 ensaios de uniformidade com milheto e crotalária spectabilis, em cultivo solteiro e em consórcio. Foi avaliada a massa de matéria fresca em 540 unidades experimentais básicas (UEB) de $1 \times 1 \mathrm{~m}$ (15 ensaios $\times 36$ UEB por ensaio). Foi estimado o índice de heterogeneidade de Smith (1938). Foi determinado o tamanho de parcela por meio do método de Hatheway (1961) em cenários formados pelas combinações de i tratamentos $(i=5,10,15,20$ e 25), $r$ repetições $(r=3,4,5,6,7,8,9$ e 10) e $d$ níveis de precisão $(d=4$, $5,6,7,8,9,10,11,12,13,14,15,16,17,18,19$ e 20\%). Para avaliar a massa de matéria fresca de milheto e de crotalária spectabilis, em cultivo solteiro ou em consórcio, com 5 a 25 tratamentos e com cinco repetições, parcelas de $10 \mathrm{~m}^{2}$ de área útil são suficientes para que diferenças entre tratamentos de $9 \%$ da média geral do experimento sejam consideradas significativas a 0,05 de probabilidade.

Palavras-chave: Crotalaria spectabilis; tamanho ótimo de parcela; Pennisetum glaucum L.; número de repetições; cultura de cobertura de solo

\footnotetext{
*Alberto Cargnelutti Filho - E-mail: alberto.cargnelutti.filho@gmail.com (Corresponding author)

Associate Editor: Mario de Andrade Lira Júnior
} 


\section{Introduction}

Millet (Pennisetum glaucum L.) and showy rattlebox (Crotalaria spectabilis Roth.) have been studied with respect to soil cover rate, decomposition rate, nutrient content, and phytomass production (Passos et al., 2017; Scavazza et al., 2018; Ferreira et al., 2019; Pfüller et al., 2019). Also, the effects on soil chemical and physical properties (Passos et al., 2017; Sousa et al., 2017), nematodes (Debiasi et al., 2016; Nascimento et al., 2020), weeds (São Miguel et al., 2018) and, consequently, on soybean (Debiasi et al., 2016; São Miguel et al., 2018) and okra (Nascimento et al., 2020) productivity have been investigated. In these researches, beneficial aspects of these ground cover species in single and intercropping were pointed out.

Such experiments were conducted with three repetitions and plots of $24 \mathrm{~m}^{2}$ (Ferreira et al., 2019), four repetitions and plots of $10 \mathrm{~m}^{2}$ (Nascimento et al., 2020); $12 \mathrm{~m}^{2}$ (Pfüller et al., 2019); $50 \mathrm{~m}^{2}$ (Passos et al., 2017); $60 \mathrm{~m}^{2}$ (Debiasi et al., 2016); $63 \mathrm{~m}^{2}$ (São Miguel et al., 2018); and $150 \mathrm{~m}^{2}$ (Sousa et al., 2017) and six repetitions and plots of $30 \mathrm{~m}^{2}$ (Scavazza et al., 2018). However, the criteria used to define the plot size and the number of repetitions were not mentioned.

From the uniformity trial data (trials without treatments) it is possible to apply Smith (1938) and Hatheway (1961) methodologies to calculate the optimal plot size according to the experimental design, the number of treatments, the number of repetitions, and the experimental precision. These methodologies have been used in sunflower (Sousa et al., 2016), in banana (Donato et al., 2018), in forage palm (Guimarães et al., 2020) and in species with potential for ground cover, such as: velvet bean (Cargnelutti Filho et al., 2014a); forage turnip (Cargnelutti Filho et al., 2014b); flax (Cargnelutti Filho et al., 2018); and black oats with common vetch (Cargnelutti Filho et al., 2020).

Plot size has been investigated in single cropping of millet (Pennisetum glaucum L.), cv. comum (Burin et al., 2015, 2016) and sunn hemp (Crotalaria juncea L.) (Facco et al., 2017) by averages of the maximum curvature method of the coefficient of variation model (Paranaíba et al., 2009). It is assumed that intercropping, commonly used with ground covers, can generate different experimental design patterns and that the use of Smith (1938) and Hatheway (1961) methodologies with another millet cultivar and another crotalaria species can add important information to the planning of experiments with these two ground covers.

Thus, the objective of this work was to determine the optimal plot size for evaluating the mass of fresh matter of millet (Pennisetum glaucum L.) and showy rattlebox (Crotalaria spectabilis), in scenarios formed by combinations of treatment numbers, repetitions numbers, and levels of experimental precision.

\section{Materials and Methods}

Fifteen uniformity trials with millet (Pennisetum glaucum L.), cultivar BRS 1501 (M), and showy rattlebox (Crotalaria spectabilis) (CS), were conducted in an experimental area located at $29^{\circ} 42^{\prime} \mathrm{S}, 53^{\circ} 49^{\prime} \mathrm{W}$ and $95 \mathrm{~m}$ altitude. At this site, the climate is Cfa humid subtropical, according to Köppen classification, with hot summers and no dry season (Alvares et al., 2013) and the soil is Arenic Dystrophic Red Argissolo (Santos et al., 2018). Physical and chemical analysis of the soil at a depth of $0-20 \mathrm{~cm}$ revealed: $\mathrm{pH}$ water 1:1: 5.2; Ca: $4.8 \mathrm{cmol} \mathrm{dm}^{-3}$; $\mathrm{Mg}: 1.5 \mathrm{cmol}_{\mathrm{c}} \mathrm{dm}^{-3}$; $\mathrm{Al}: 0.3 \mathrm{cmol}_{\mathrm{c}} \mathrm{dm}^{-3} ; \mathrm{H}+\mathrm{Al}$ : $8.7 \mathrm{cmol}_{\mathrm{c}} \mathrm{dm}^{-3}$; SMP index: 5.4; organic matter: $2.3 \%$; clay content: $24.0 \%$; S: $15.3 \mathrm{mg} \mathrm{dm}^{-3}$; P (Mehlich): $43.9 \mathrm{mg} \mathrm{dm}^{-3}$; K: $0.593 \mathrm{cmol}_{\mathrm{c}} \mathrm{dm}^{-3} ; \mathrm{CTC}_{\mathrm{pH}}: 15.6 \mathrm{cmol}_{\mathrm{c}} \mathrm{dm}^{-3} ; \mathrm{Cu}: 1.77 \mathrm{mg} \mathrm{dm}^{-3}$; $\mathrm{Zn}: 1.04 \mathrm{mg} \mathrm{dm}^{-3}$; and B: $0.3 \mathrm{mg} \mathrm{dm}^{-3}$.

Three uniformity trials (repetitions) were conducted of each of the following five compositions, with the respective

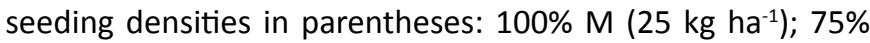
M $\left(18.75 \mathrm{~kg} \mathrm{ha}^{-1}\right)+25 \%$ CS $\left(4.6875 \mathrm{~kg} \mathrm{ha}^{-1}\right) ; 50 \% \mathrm{M}(12.5 \mathrm{~kg}$ $\left.\mathrm{ha}^{-1}\right)+50 \%$ CS $\left(9.375 \mathrm{~kg} \mathrm{ha}^{-1}\right) ; 25 \% \mathrm{M}\left(6.25 \mathrm{~kg} \mathrm{ha}^{-1}\right)+75 \% \mathrm{CS}$ (14.0625 kg ha-1); and $100 \%$ CS (18.75 kg ha $\left.{ }^{-1}\right)$. On November 13,2019 , base fertilization was performed, with $20 \mathrm{~kg} \mathrm{ha}^{-1}$ of $\mathrm{N}, 80 \mathrm{~kg} \mathrm{ha}^{-1}$ of $\mathrm{P}_{2} \mathrm{O}_{5}$ and $80 \mathrm{~kg} \mathrm{ha}^{-1}$ of $\mathrm{K}_{2} \mathrm{O}(\mathrm{N}-\mathrm{P}-\mathrm{K}$, formulation 05-20-20) and broadcast sowing. On December 18, 2019, 40 $\mathrm{kg} \mathrm{ha}^{-1}$ of $\mathrm{N}$ was applied, in the form of urea.

In each uniformity trial, the central area of size $6 \times 6 \mathrm{~m} \mathrm{(36}$ $\mathrm{m}^{2}$ ) was divided into 36 basic experimental units (BEU) of $1 \times$ $1 \mathrm{~m}\left(1 \mathrm{~m}^{2}\right)$, forming a matrix of six rows and six columns. On February $3^{\text {rd }}$ and $4^{\text {th }}, 2020$, at the flowering of millet plants, in each BEU, the plants were cut, close to the soil surface, and the mass of fresh matter (FM) was weighed, in $\mathrm{g} \mathrm{m}^{-2}$. It was decided to cut the millet at flowering, to minimize the effects on the mass of fresh matter due to leaf senescence of the crop after this period. Weighing was performed immediately after cutting, in order to minimize possible variations in plant moisture.

For each uniformity trial, from the FM data of the $36 \mathrm{BEU}$, plots with $X_{R}$ BEU adjacent in the row and $X_{C}$ BEU adjacent in the column were planned. The plots with distinct sizes and/or shapes were planned as $\left(X=X_{R} \times X_{C}\right)$, i.e., $(1 \times 1),(1 \times 2)$, $(1 \times 3),(1 \times 6),(2 \times 1),(2 \times 2),(2 \times 3),(2 \times 6),(3 \times 1),(3 \times 2),(3 \times 3)$, $(3 \times 6),(6 \times 1),(6 \times 2)$, and $(6 \times 3)$. The abbreviations $X_{R}, x_{C}$ and $X$, stand for number of adjacent BEU in the row, number of adjacent BEU in the column and plot size in number of BEU, respectively.

For each plot size $(X)$ were determined: $n$ - number of plots with $X$ BEU of size $(n=36 / X) ; M_{(X)}$ - average of the plots with $X$ BEU size; $V_{(X)}$ - variance among plots of $X$ BEU size; $\mathrm{CV}_{(X)}$ coefficient of variation (in \%) among plots of $X$ BEU size; and $V U_{(X)}$ - variance per BEU among the plots of $X$ BEU size $\left[\mathrm{VU}_{(\mathrm{X})}=\mathrm{V}_{(\mathrm{X})} / \mathrm{X}^{2}\right]$.

The parameters $\mathrm{V} 1$ (variance per BEU among the plots of a BEU size) and $b$ (index of heterogeneity) and the coefficient of determination $\left(r^{2}\right)$ of the function $V U_{(X)}=V 1 / X^{b}$ of Smith (1938) were estimated. These parameters were estimated by logarithmic transformation and linearization of the function $V U_{(x)}=V 1 / X^{b}$, i.e., $\log V U_{(X)}=\log V 1-b \log X$, whose estimation was weighted by the degrees of freedom (DF=n-1), associated with each plot size, as applied by Sousa et al. (2016). The 
observed values of the dependent $[\mathrm{VU} \mathrm{(X)}]$ and independent $(\mathrm{X})$ variables and the function $\mathrm{VU}_{(\mathrm{X})}=\mathrm{V} 1 / \mathrm{X}^{\mathrm{b}}$ (Smith, 1938) were plotted graphically.

Experimental plans were simulated for the scenarios formed by combinations of $i$ treatments $(i=5,10,15,20$, and 25), $r$ repetitions $(r=3,4,5,6,7,8,9$, and 10) and $d$ differences between treatment averages to be detected as significant at 0.05 probability, expressed as a percentage of the overall average of the experiment, i.e., in levels of precision $[d=4 \%$ (highest precision), $5,6,7,8,9,10,11,12$, $13,14,15,16,17,18,19$, and $20 \%$ (lowest precision)]. For each experimental plan, the optimal plot size (Xo), in number of BEU, was calculated using the expression

$$
\mathrm{Xo}=\sqrt[b]{\frac{2\left(\mathrm{t}_{1}+\mathrm{t}_{2}\right)^{2} \mathrm{CV}^{2}}{\mathrm{rd}^{2}}}(\text { Hatheway, 1961) }
$$

In this expression $b$ is the estimate of the heterogeneity index (in this study, the average of $b$ from the 15 uniformity trials was taken); $t_{1}$ is the critical value of Student's $t$ distribution for the significance level of the test (type I error) of $\alpha=5 \%$ (two-sided test at 5\%), with DF degrees of freedom; $t_{2}$ is the critical value of Student's $t$ distribution, corresponding to 2(1-P) (two-sided test), where $P$ is the probability of obtaining a significant result, that is, the power of the test $(P$ $=0.80$, in this study), with DF degrees of freedom; CV is the estimate of the coefficient of variation among plots of a BEU size (in this study, the average CV of the 15 uniformity trials was taken), in percent; $r$ is the number of repetitions and $d$ is the difference between treatment averages to be detected as significant at 0.05 probability, expressed as a percentage of the overall average of the experiment (precision). The degrees of freedom (DF) for obtaining the critical values (tabulated) of Student's t-distribution were obtained by the expression $D F=(i)(r-1)$, where $i$ is the number of treatments and $r$ is the number of repetitions. The values of $t_{1}$ and $t_{2}$, in this study, were obtained with the Microsoft Office Excel ${ }^{\circ}$ software, through the functions $t_{1}=\operatorname{INVT}(0.05 ; D F)$ and $t_{2}=I N V T(0.40 ; D F)$, respectively.

The data of FM, CV and b, obtained in the three uniformity trials (repetitions) of each of the five compositions, were submitted to analysis of variance and Scott Knott test via bootstrap with 10,000 resamples, with the aid of Sisvar software (Ferreira, 2014). These statistical procedures are suitable to circumvent possible impacts of not meeting the assumptions of normality of errors and homogeneity of residual variances (Ferreira, 2014). The other statistical analyses were performed with the help of Microsoft Office Excel $^{\circledR}$ software.

\section{Results and Discussion}

In the 15 uniformity trials, formed by compositions of sowing densities of millet (Pennisetum glaucum L.), cultivar BRS 1501 (M) and showy rattlebox (Crotalaria spectabilis
Roth.) (CS), the mass of fresh matter (FM) ranged between 4382 and $8276 \mathrm{~g} \mathrm{~m}^{-2}$, i.e., 43.82 and $82.76 \mathrm{Mg} \mathrm{ha}^{-1}$, respectively (Table 1). The average FM, from the three trials for each composition were 7117, 7442, 7861, 7955, and $4593 \mathrm{~g} \mathrm{~m}^{-2}$, for the compositions of $100 \% \mathrm{M}, 75 \% \mathrm{M}+25 \% \mathrm{CS}, 50 \% \mathrm{M}$ + 50\% CS, $25 \% \mathrm{M}+75 \% \mathrm{CS}$, and $100 \% \mathrm{CS}$, respectively. Two groups of averages were formed by Scott Knott bootstrap test at $5 \%$ significance level. The average FM of the composition with millet alone and of the compositions in intercropping, did not differ, and were higher than the FM produced by showy rattlebox in single cropping. For these same millet and showy rattlebox cultivars, 34.59 and $33.9 \mathrm{Mg} \mathrm{ha}^{-1}$ of FM were obtained by Passos et al. (2017) and 5.327 and 1.67 $\mathrm{Mg} \mathrm{ha}^{-1}$ by Pfüller et al. (2019), respectively.

The coefficient of variation (CV) of FM, obtained among the $36 \mathrm{BEU}$ in each of the 15 uniformity trials, ranged from 9.87 to $18.51 \%$, with an average of $14.62 \%$ (Table 1 ). The average $\mathrm{CV}$, of the three trials of each composition, was $14.49,14.82,15.85,14.85$, and $13.07 \%$, for the compositions of $100 \% \mathrm{M}, 75 \% \mathrm{M}+25 \% \mathrm{CS}, 50 \% \mathrm{M}+50 \% \mathrm{CS}, 25 \% \mathrm{M}+$ $75 \% \mathrm{CS}$, and $100 \% \mathrm{CS}$, respectively, and by the F-test of the analysis of variance, they did not differ ( $p$-value $=0.7599)$. This suggests that experiments with millet and showy rattlebox, in

Table 1. Mass of fresh matter (FM), coefficient of variation (CV) and index of heterogeneity (b) of Smith (1938), in three uniformity trials (repetitions) of each of the five compositions of millet (M) and showy rattlebox (CS) sowing densities. F-test value and respective $p$-value of the analysis of variance via bootstrap with 10,000 resamples, for FM, CV and $b$.

\begin{tabular}{|c|c|c|c|c|}
\hline Composition & Trial (1) & $\begin{array}{c}F M \\
\left(\mathrm{~g} \mathrm{~m}^{-2}\right)^{(2)}\end{array}$ & $\begin{array}{c}\text { CV } \\
\text { (\%) (3) }\end{array}$ & $b^{(3)}$ \\
\hline \multirow{4}{*}{$100 \% \mathrm{M}$} & 1 & 6979 & 16.03 & 0.6828 \\
\hline & 2 & 6841 & 13.76 & 0.5453 \\
\hline & 3 & 7532 & 13.68 & 0.6995 \\
\hline & Average & $7117 \mathrm{a}$ & 14.49 & 0.6425 \\
\hline \multirow{4}{*}{$75 \% M+25 \% \mathrm{CS}$} & 1 & 6993 & 15.89 & 1.0487 \\
\hline & 2 & 7181 & 16.30 & 0.7891 \\
\hline & 3 & 8151 & 12.26 & 1.0379 \\
\hline & Average & $7442 \mathrm{a}$ & 14.82 & 0.9586 \\
\hline \multirow{4}{*}{$50 \% M+50 \% C S$} & 1 & 8276 & 18.51 & 1.3545 \\
\hline & 2 & 7465 & 13.90 & 0.9625 \\
\hline & 3 & 7843 & 15.14 & 0.6280 \\
\hline & Average & 7861 a & 15.85 & 0.9817 \\
\hline \multirow{4}{*}{$25 \% M+75 \% C S$} & 1 & 7827 & 13.27 & 1.1609 \\
\hline & 2 & 8234 & 13.53 & 1.3363 \\
\hline & 3 & 7804 & 17.76 & 1.2871 \\
\hline & Average & 7955 a & 14.85 & 1.2615 \\
\hline \multirow{5}{*}{$100 \%$ CS } & 1 & 4382 & 17.07 & 0.7250 \\
\hline & 2 & 4656 & 12.28 & 1.0911 \\
\hline & 3 & 4742 & 9.87 & 1.0725 \\
\hline & Average & $4593 b$ & 13.07 & 0.9629 \\
\hline & Overall average & 6994 & 14.62 & 0.9614 \\
\hline $\mathrm{F}$ & & 36.889 & 0.468 & 3.404 \\
\hline$p$-value & & 0.0013 & 0.7599 & 0.0635 \\
\hline
\end{tabular}

(1) Each uniformity trial of size $6 \times 6 \mathrm{~m}\left(36 \mathrm{~m}^{2}\right)$ was divided into 36 BEU of $1 \times 1 \mathrm{~m} \mathrm{(1}$ $\mathrm{m}^{2}$ ), forming a matrix of six rows and six columns. ${ }^{(2)}$ Averages not followed by the same letter in the column (comparison of averages between compositions) differ at $5 \%$ significance by Scott Knott bootstrap test with 10,000 re-samples. ${ }^{(3)}$ The averages of the compositions do not differ ( $p>0.05$ ). 
single cropping or in intercropping, have similar experimental accuracy. Additionally, it can be inferred that using the average CV of the 15 trials (CV =14.62\%), in Hatheway (1961) methodology, is adequate to represent all compositions.

Smith (1938) heterogeneity index (b) among the 15 uniformity trials ranged from 0.5453 to 1.3545 , with an average of 0.9614 (Table 1). The averages of $b$, from the three trials for each composition were $0.6425,0.9586,0.9817,1.2615$, and 0.9629 , for the compositions of $100 \% \mathrm{M}, 75 \% \mathrm{M}+25 \% \mathrm{CS}$, $50 \% \mathrm{M}+50 \% \mathrm{CS}, 25 \% \mathrm{M}+75 \% \mathrm{CS}$, and $100 \% \mathrm{CS}$, respectively, and did not differ ( $p$-value $=0.0635)$. Then, one can use the average $b$ of the 15 trials $(b=0.9614$ ) in Hatheway (1961) methodology, to represent the five compositions. Values of $b$ close to unity indicate high heterogeneity or low correlation between adjacent plots. According to Lin \& Binns (1986), when $b>0.7$, it is recommended to increase the plot size, when $b<0.2$, one should increase the number of repetitions, and in cases of $0.2 \leq b \leq 0.7$ it is appropriate to investigate the best combination of plot size and number of repetitions. Thus, it can be inferred that in experiments of millet and showy rattlebox, in single cultivation or in intercropping, one should prioritize the use of larger size plots.

In the 15 uniformity trials, there was a decrease in the variance per BEU among plots $\left[\mathrm{VU}_{(\mathrm{X})}\right]$, which indicates improvement in experimental precision with increasing planned plot size (X) (Figure 1). The decreases were steep up to plots four BEU in size $\left(4 \mathrm{~m}^{2}\right)$, intermediate between four and ten BEU, and a stabilizing trend with plots larger than ten BEU. Similar pattern to this was observed in velvet bean (Cargnelutti Filho et al., 2014a); forage turnip (Cargnelutti Filho et al., 2014b); flax (Cargnelutti Filho et al., 2018); and black oats with common vetch (Cargnelutti Filho et al., 2020). So, to evaluate the mass of fresh matter of millet and showy rattlebox, in single cultivation or in intercropping, a plot size of up to $10 \mathrm{~m}^{2}$ is indicated. This value is relatively higher than the optimal plot size required to evaluate the mass of fresh matter of millet, cv. common, which was $4.46 \mathrm{~m}^{2}$ in three evaluation seasons (Burin et al., 2015) and $4.97 \mathrm{~m}^{2}$, for the three sowing and cutting seasons (Burin et al., 2016). It was also larger than the $2.04 \mathrm{~m}^{2}$ size (Facco et al., 2017) to evaluate the mass of fresh matter of sunn hemp. Differences among environments, millet cultivars, crotalaria species, and methodologies used for plot size determination contribute to explain the different results from those obtained in this study.

In Hatheway methodology (1961), from fixed values of the coefficient of variation ( $C V=14.62 \%$ ) and Smith heterogeneity index (1938) ( $b=0.9614)$, it is possible to determine different optimal plot sizes (Xo), as a function of the number of
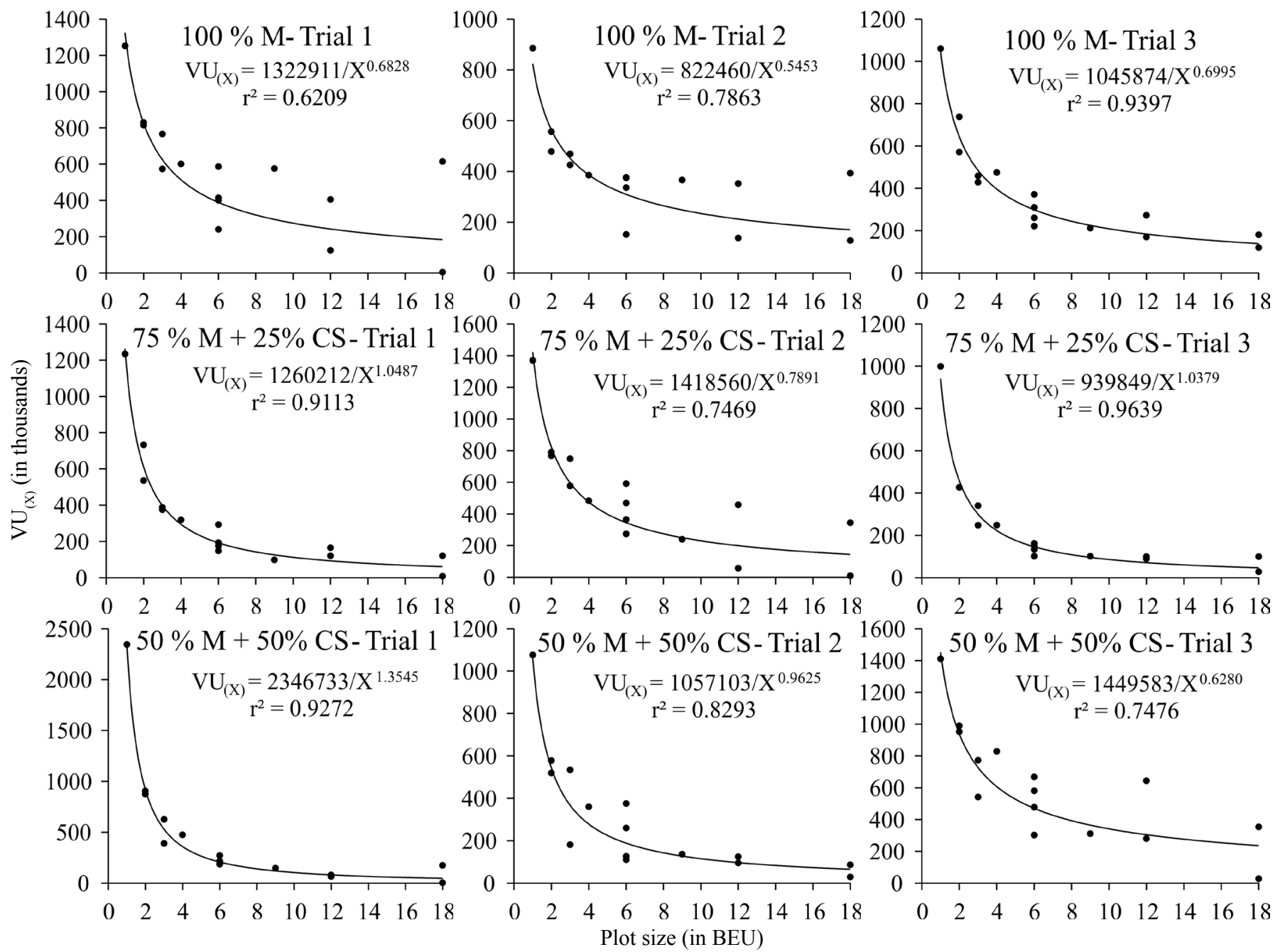

Continued on the next page 
Continued from Figure 1
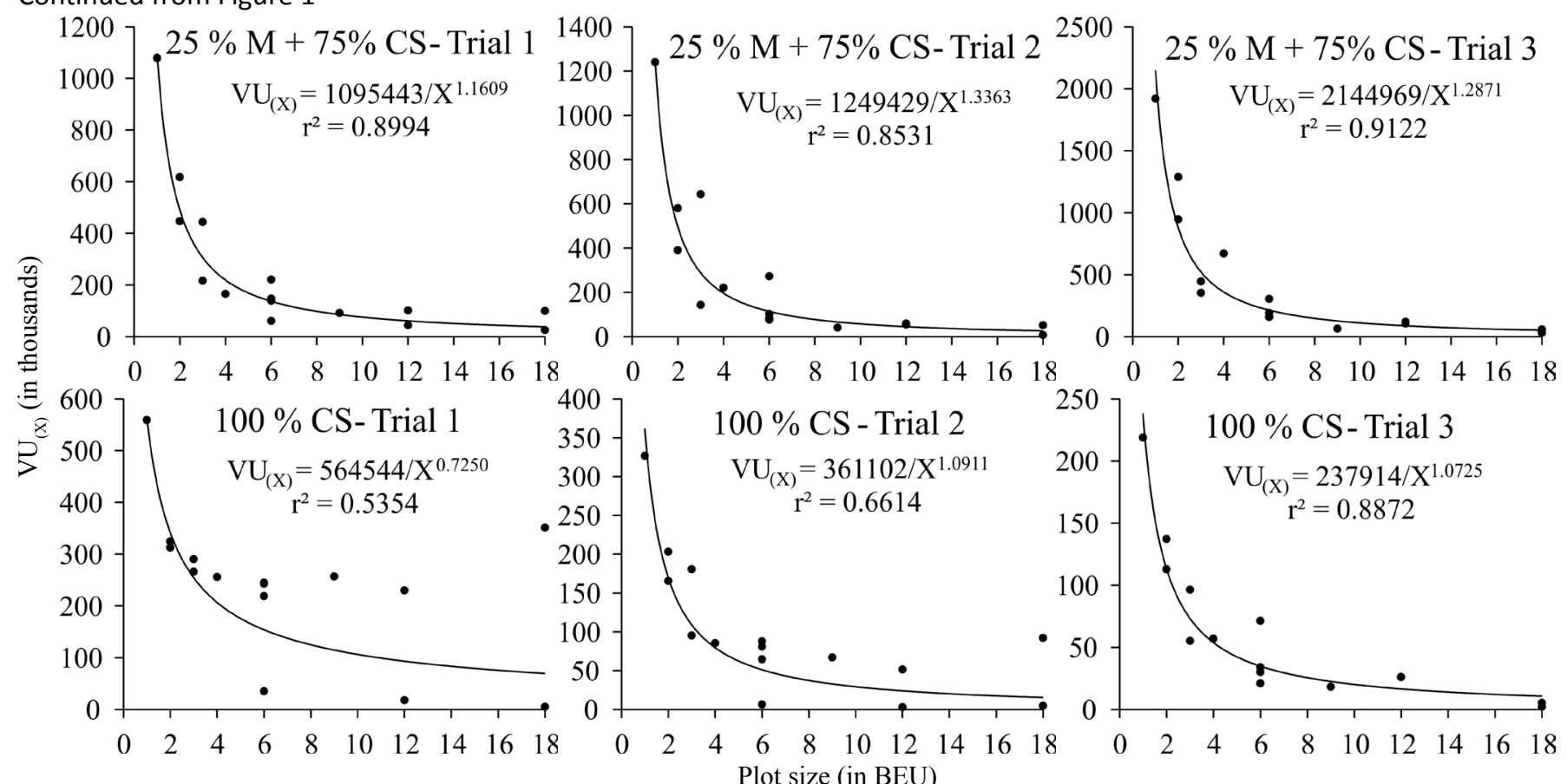

Figure 1. Relationship between the variance per basic experimental unit (BEU) between $X$ BEU plot sizes $\left[V U_{(X)}=V_{(X)} / X^{2}\right]$, in thousands, and the planned plot size $(\mathrm{X})$, in BEU, and the parameter estimates of the function $\mathrm{VU}_{(\mathrm{X})}=\mathrm{V} 1 / \mathrm{X}^{\mathrm{b}}$ of Smith (1938). Mass of fresh matter data obtained in uniformity trials, with $36 \mathrm{BEU}$ of $1 \mathrm{~m}^{2}$, formed by compositions of sowing densities of millet (Pennisetum glaucum L.), cultivar BRS 1501 (M), and showy rattlebox (Crotalaria spectabilis), common cultivar (CS).

treatments (i), the number of repetitions $(r)$, and precision $\mathrm{m}^{2}$, the researcher can investigate within his availability of (d) (Table 2). Therefore, besides the indicated size of 10 experimental area, number of treatments to be evaluated and

Table 2. Optimum plot size, in $\mathrm{m}^{2}$, in combinations of $\mathrm{i}$ treatments, $\mathrm{r}$ repetitions and $\mathrm{d}$ precision levels (\%), for mass of fresh matter in compositions of millet and showy rattlebox sowing densities ( $C V=14.62 \%$; heterogeneity index $b=0.9614$ ).

\begin{tabular}{|c|c|c|c|c|c|c|c|c|c|c|c|c|c|c|c|c|c|c|}
\hline \multirow{2}{*}{$\mathbf{i}$} & \multirow[b]{2}{*}{$\mathbf{r}$} & \multicolumn{17}{|c|}{ d (\%) } \\
\hline & & 4 & 5 & 6 & 7 & 8 & 9 & 10 & 11 & 12 & 13 & 14 & 15 & 16 & 17 & 18 & 19 & 20 \\
\hline \multirow{8}{*}{5} & 3 & 102.8 & 64.6 & 44.2 & 32.1 & 24.3 & 19.0 & 15.3 & 12.5 & 10.5 & 8.9 & 7.6 & 6.6 & 5.7 & 5.1 & 4.5 & 4.0 & 3.6 \\
\hline & 4 & 70.7 & 44.5 & 30.4 & 22.1 & 16.7 & 13.1 & 10.5 & 8.6 & 7.2 & 6.1 & 5.2 & 4.5 & 4.0 & 3.5 & 3.1 & 2.8 & 2.5 \\
\hline & 5 & 54.1 & 34.0 & 23.3 & 16.9 & 12.8 & 10.0 & 8.0 & 6.6 & 5.5 & 4.7 & 4.0 & 3.5 & 3.0 & 2.7 & 2.4 & 2.1 & 1.9 \\
\hline & 6 & 43.8 & 27.5 & 18.8 & 13.7 & 10.4 & 8.1 & 6.5 & 5.3 & 4.5 & 3.8 & 3.2 & 2.8 & 2.4 & 2.2 & 1.9 & 1.7 & 1.5 \\
\hline & 7 & 36.8 & 23.1 & 15.8 & 11.5 & 8.7 & 6.8 & 5.5 & 4.5 & 3.7 & 3.2 & 2.7 & 2.4 & 2.1 & 1.8 & 1.6 & 1.4 & 1.3 \\
\hline & 8 & 31.7 & 19.9 & 13.6 & 9.9 & 7.5 & 5.9 & 4.7 & 3.9 & 3.2 & 2.7 & 2.3 & 2.0 & 1.8 & 1.6 & 1.4 & 1.2 & 1.1 \\
\hline & 9 & 27.8 & 17.5 & 12.0 & 8.7 & 6.6 & 5.2 & 4.1 & 3.4 & 2.8 & 2.4 & 2.1 & 1.8 & 1.6 & 1.4 & 1.2 & 1.1 & 1.0 \\
\hline & 10 & 24.8 & 15.6 & 10.7 & 7.7 & 5.9 & 4.6 & 3.7 & 3.0 & 2.5 & 2.1 & 1.8 & 1.6 & 1.4 & 1.2 & 1.1 & 1.0 & 0.9 \\
\hline \multirow{8}{*}{10} & 3 & 92.0 & 57.9 & 39.6 & 28.7 & 21.8 & 17.0 & 13.7 & 11.2 & 9.4 & 7.9 & 6.8 & 5.9 & 5.1 & 4.5 & 4.0 & 3.6 & 3.2 \\
\hline & 4 & 65.8 & 41.4 & 28.3 & 20.6 & 15.6 & 12.2 & 9.8 & 8.0 & 6.7 & 5.7 & 4.9 & 4.2 & 3.7 & 3.2 & 2.9 & 2.6 & 2.3 \\
\hline & 5 & 51.3 & 32.3 & 22.1 & 16.0 & 12.1 & 9.5 & 7.6 & 6.3 & 5.2 & 4.4 & 3.8 & 3.3 & 2.9 & 2.5 & 2.2 & 2.0 & 1.8 \\
\hline & 6 & 42.0 & 26.4 & 18.1 & 13.1 & 9.9 & 7.8 & 6.2 & 5.1 & 4.3 & 3.6 & 3.1 & 2.7 & 2.3 & 2.1 & 1.8 & 1.6 & 1.5 \\
\hline & 7 & 35.5 & 22.3 & 15.3 & 11.1 & 8.4 & 6.6 & 5.3 & 4.3 & 3.6 & 3.1 & 2.6 & 2.3 & 2.0 & 1.8 & 1.6 & 1.4 & 1.2 \\
\hline & 8 & 30.8 & 19.3 & 13.2 & 9.6 & 7.3 & 5.7 & 4.6 & 3.8 & 3.1 & 2.7 & 2.3 & 2.0 & 1.7 & 1.5 & 1.3 & 1.2 & 1.1 \\
\hline & 9 & 27.1 & 17.1 & 11.7 & 8.5 & 6.4 & 5.0 & 4.0 & 3.3 & 2.8 & 2.3 & 2.0 & 1.7 & 1.5 & 1.3 & 1.2 & 1.1 & 1.0 \\
\hline & 10 & 24.2 & 15.2 & 10.4 & 7.6 & 5.7 & 4.5 & 3.6 & 3.0 & 2.5 & 2.1 & 1.8 & 1.6 & 1.4 & 1.2 & 1.1 & 0.9 & 0.9 \\
\hline \multirow{8}{*}{15} & 3 & 88.8 & 55.8 & 38.2 & 27.7 & 21.0 & 16.4 & 13.2 & 10.8 & 9.0 & 7.6 & 6.6 & 5.7 & 5.0 & 4.4 & 3.9 & 3.5 & 3.1 \\
\hline & 4 & 64.3 & 40.4 & 27.7 & 20.1 & 15.2 & 11.9 & 9.6 & 7.8 & 6.5 & 5.5 & 4.7 & 4.1 & 3.6 & 3.2 & 2.8 & 2.5 & 2.3 \\
\hline & 5 & 50.4 & 31.7 & 21.7 & 15.7 & 11.9 & 9.3 & 7.5 & 6.1 & 5.1 & 4.3 & 3.7 & 3.2 & 2.8 & 2.5 & 2.2 & 2.0 & 1.8 \\
\hline & 6 & 41.4 & 26.0 & 17.8 & 12.9 & 9.8 & 7.7 & 6.2 & 5.1 & 4.2 & 3.6 & 3.1 & 2.6 & 2.3 & 2.0 & 1.8 & 1.6 & 1.5 \\
\hline & 7 & 35.1 & 22.1 & 15.1 & 11.0 & 8.3 & 6.5 & 5.2 & 4.3 & 3.6 & 3.0 & 2.6 & 2.2 & 2.0 & 1.7 & 1.5 & 1.4 & 1.2 \\
\hline & 8 & 30.5 & 19.2 & 13.1 & 9.5 & 7.2 & 5.6 & 4.5 & 3.7 & 3.1 & 2.6 & 2.2 & 1.9 & 1.7 & 1.5 & 1.3 & 1.2 & 1.1 \\
\hline & 9 & 26.9 & 16.9 & 11.6 & 8.4 & 6.4 & 5.0 & 4.0 & 3.3 & 2.7 & 2.3 & 2.0 & 1.7 & 1.5 & 1.3 & 1.2 & 1.1 & 0.9 \\
\hline & 10 & 24.1 & 15.1 & 10.3 & 7.5 & 5.7 & 4.5 & 3.6 & 2.9 & 2.4 & 2.1 & 1.8 & 1.5 & 1.3 & 1.2 & 1.1 & 0.9 & 0.8 \\
\hline
\end{tabular}


Continued from Table 2

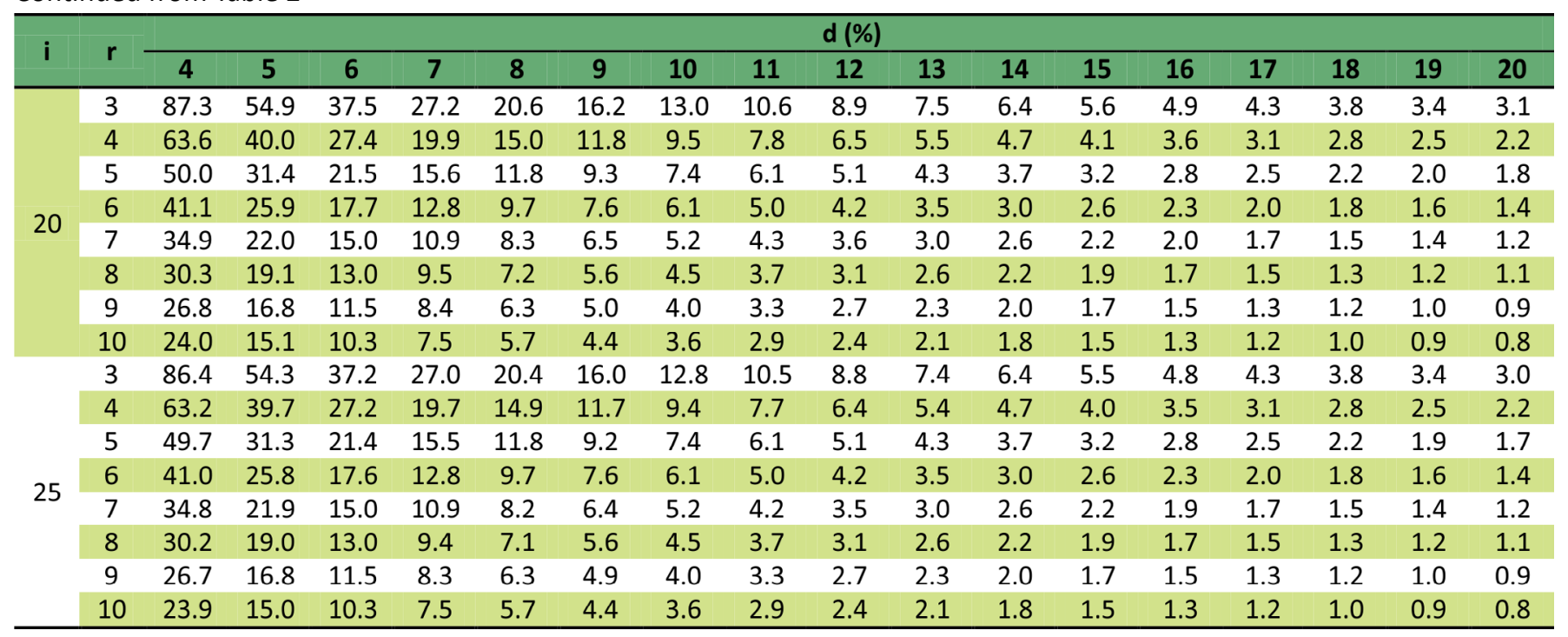

desired precision, which combination of plot size and number of repetitions is the most appropriate.

With fixed values of $i$ and $r$, Xo increased with increasing accuracy (d) (Table 2). For example, to evaluate FM in an experiment conducted in completely randomized design (CRD), with five treatments and three repetitions, aiming that in $80 \%$ of the experiments (power $=0.80$ ) differences between treatments of $d=20 \%$ of the overall average of the experiment (lower precision) are detected as significant at $5 \%$ probability, the plot size should be $3.6 \mathrm{BEU}\left(3.6 \mathrm{~m}^{2}\right.$ ) (Table 2 ). At the other extreme, i.e. plots of $102.8 \mathrm{~m}^{2}$ would make it possible to improve accuracy and obtain $d=4 \%$. However, conducting a field experiment with a $102.8 \mathrm{~m}^{2}$ plot requires a larger experimental area and can make the experiment difficult to execute. In practice, high experimental accuracies (low percentages of $d$ ) are difficult to achieve because of the need for high plot size, as already pointed out by Cargnelutti Filho et al. (2014a, 2014b, 2018, 2020). Additionally, with fixed values of $i$ and $d$, Xo decreased with the increase of $r$, and with fixed values of $r$ and $d$, Xo decreased with the increase of i. Similar pattern has been found by Cargnelutti Filho et al. (2014a, 2014b, 2018, 2020).

The information from this study enables investigations into 480 scenarios formed by combinations of i treatments $(i=5,10,15,20$, and 25$), r$ repetitions $(r=3,4,5,6,7,8$, 9 , and 10) and $d$ differences between treatment averages to be detected as significant at $5 \%$ probability $(d=4,5,6$, $7,8,9,10,11,12,13,14,15,16,17,18,19$, and 20\%). For example, if the researcher wants to evaluate the FM of five treatments, in CRD, and wants precision (d) of $10 \%$, among the various options, he could use plots of $15.3 \mathrm{BEU}\left(15.3 \mathrm{~m}^{2}\right)$ and three repetitions, $10.5 \mathrm{BEU}\left(10.5 \mathrm{~m}^{2}\right)$ and four repetitions, 8.0 BEU $\left(8.0 \mathrm{~m}^{2}\right)$ and five repetitions, $6.5 \mathrm{BEU}\left(6.5 \mathrm{~m}^{2}\right)$ and six repetitions, $5.5 \mathrm{BEU}\left(5.5 \mathrm{~m}^{2}\right)$ and seven repetitions, 4.7 $\mathrm{BEU}\left(4.7 \mathrm{~m}^{2}\right)$ and eight repetitions, $4.1 \mathrm{BEU}\left(4.1 \mathrm{~m}^{2}\right)$ and nine repetitions and $3.7 \mathrm{BEU}\left(3.7 \mathrm{~m}^{2}\right)$ and ten repetitions (Table 2). In this situation, the required experimental area is 229, 210, $201,195,191,188,186$, and $184 \mathrm{~m}^{2}$, respectively (Table 3 ).
Other scenarios can be simulated using the expression

$$
\mathrm{Xo}=\sqrt[b]{\frac{2\left(\mathrm{t}_{1}+\mathrm{t}_{2}\right)^{2} \mathrm{CV}^{2}}{\mathrm{rd}^{2}}} \text { (Hatheway, 1961). }
$$

For example, to evaluate the FM of eight treatments, with five repetitions and with $d=9 \%$, in CRD, one has: $\mathrm{b}=0.9614 ; \quad \mathrm{DF}=(8)(5-1)=32 ; \mathrm{t}_{1}=\operatorname{INVT}(0.05 ; 32)=2.036933334$; $\mathrm{t}_{2}=\operatorname{INVT}(0.40 ; 32)=0.85299845 ; \quad C V=14.62 \% ; \quad r=5 ; \quad d=9 \%$. Therefore,

$$
\mathrm{Xo}=\sqrt[0.9614]{\frac{2(2.036933334+0.85299845)^{2} 14.62^{2}}{5 \cdot 9^{2}}}=9.6 \mathrm{BEU}
$$

If the researcher wants to conduct the experiment in a randomized complete block design, he has: $b=0.9614$; $\mathrm{DF}=(8-1)(5-1)=28 ; \quad \mathrm{t}_{1}=\operatorname{INVT}(0.05 ; 28)=2.048407115$; $\mathrm{t}_{2}=\operatorname{INVT}(0.40 ; 28)=0.85464749 ; \quad C V=14.62 \% ; \quad r=5 ; \quad d=9 \%$. Therefore,

$$
\mathrm{Xo}=\sqrt[0.9614]{\frac{2(2.048407115+0.85464749)^{2} 14.62^{2}}{5 \cdot 9^{2}}}=9.7 \mathrm{BEU}
$$

Therefore, using the criterion of rounding up to the nearest whole number to ensure the desired precision, for these examples, the plot size would be $10 \mathrm{~m}^{2}$ and the experimental area $400 \mathrm{~m}^{2}$

The results of this study serve as a reference for defining the plot size and the number of repetitions in experiments to evaluate the mass of fresh matter of millet and showy rattlebox, cultivated alone or in intercropping. In other cultures, such as: sunflower (Sousa et al., 2016); banana (Donato et al., 2018); forage palm (Guimarães et al., 2020); velvet bean (Cargnelutti Filho et al., 2014a); forage turnip (Cargnelutti Filho et al., 2014b); flax (Cargnelutti Filho et al., 
Table 3. Experiment size, in $\mathrm{m}^{2}$, in combinations of $\mathrm{i}$ treatments, $\mathrm{r}$ repetitions and d precision levels (\%), for mass of fresh matter in compositions of millet and showy rattlebox sowing densities ( $C V=14.62 \%$; heterogeneity index $b=0.9614$ ).

\begin{tabular}{|c|c|c|c|c|c|c|c|c|c|c|c|c|c|c|c|c|c|c|}
\hline \multirow{2}{*}{$\mathbf{i}$} & \multirow{2}{*}{$r$} & \multicolumn{17}{|c|}{$d(\%)$} \\
\hline & & 4 & 5 & 6 & 7 & 8 & 9 & 10 & 11 & 12 & 13 & 14 & 15 & 16 & 17 & 18 & 19 & 20 \\
\hline \multirow{8}{*}{5} & 3 & 1542 & 970 & 664 & 481 & 365 & 285 & 229 & 188 & 157 & 133 & 114 & 99 & 86 & 76 & 67 & 60 & 54 \\
\hline & 4 & 1415 & 890 & 609 & 442 & 335 & 262 & 210 & 173 & 144 & 122 & 104 & 90 & 79 & 70 & 62 & 55 & 50 \\
\hline & 5 & 1352 & 850 & 582 & 422 & 320 & 250 & 201 & 165 & 138 & 116 & 100 & 86 & 76 & 67 & 59 & 53 & 48 \\
\hline & 6 & 1314 & 826 & 565 & 410 & 311 & 243 & 195 & 160 & 134 & 113 & 97 & 84 & 73 & 65 & 58 & 51 & 46 \\
\hline & 7 & 1288 & 810 & 554 & 402 & 305 & 238 & 191 & 157 & 131 & 111 & 95 & 82 & 72 & 63 & 56 & 50 & 45 \\
\hline & 8 & 1268 & 797 & 546 & 396 & 300 & 235 & 188 & 155 & 129 & 109 & 94 & 81 & 71 & 63 & 55 & 50 & 45 \\
\hline & 9 & 1253 & 787 & 539 & 391 & 296 & 232 & 186 & 153 & 127 & 108 & 92 & 80 & 70 & 62 & 55 & 49 & 44 \\
\hline & 10 & 1240 & 780 & 534 & 387 & 293 & 230 & 184 & 151 & 126 & 107 & 92 & 79 & 69 & 61 & 54 & 49 & 44 \\
\hline \multirow{8}{*}{10} & 3 & 2761 & 1736 & 1188 & 862 & 653 & 511 & 410 & 337 & 281 & 238 & 204 & 177 & 154 & 136 & 121 & 108 & 97 \\
\hline & 4 & 2634 & 1656 & 1133 & 822 & 623 & 487 & 392 & 321 & 268 & 227 & 194 & 168 & 147 & 130 & 115 & 103 & 93 \\
\hline & 5 & 2565 & 1613 & 1104 & 801 & 607 & 475 & 381 & 313 & 261 & 221 & 189 & 164 & 143 & 126 & 112 & 100 & 90 \\
\hline & 6 & 2520 & 1584 & 1084 & 787 & 596 & 466 & 375 & 307 & 256 & 217 & 186 & 161 & 141 & 124 & 110 & 99 & 89 \\
\hline & 7 & 2487 & 1564 & 1070 & 776 & 588 & 460 & 370 & 303 & 253 & 214 & 184 & 159 & 139 & 123 & 109 & 97 & 87 \\
\hline & 8 & 2462 & 1548 & 1059 & 769 & 582 & 456 & 366 & 300 & 250 & 212 & 182 & 157 & 138 & 121 & 108 & 96 & 87 \\
\hline & 9 & 2441 & 1535 & 1050 & 762 & 577 & 452 & 363 & 298 & 248 & 210 & 180 & 156 & 137 & 120 & 107 & 95 & 86 \\
\hline & 10 & 2424 & 1524 & 1043 & 757 & 573 & 449 & 360 & 296 & 247 & 209 & 179 & 155 & 136 & 119 & 106 & 95 & 85 \\
\hline \multirow{8}{*}{15} & 3 & 3997 & 2513 & 1719 & 1248 & 945 & 740 & 594 & 487 & 407 & 344 & 295 & 256 & 223 & 197 & 175 & 156 & 140 \\
\hline & 4 & 3860 & 2427 & 1661 & 1205 & 913 & 714 & 574 & 471 & 393 & 332 & 285 & 247 & 216 & 190 & 169 & 151 & 136 \\
\hline & 5 & 3782 & 2377 & 1627 & 1181 & 894 & 700 & 562 & 461 & 385 & 326 & 279 & 242 & 211 & 186 & 166 & 148 & 133 \\
\hline & 6 & 3728 & 2344 & 1604 & 1164 & 882 & 690 & 554 & 455 & 379 & 321 & 275 & 238 & 208 & 184 & 163 & 146 & 131 \\
\hline & 7 & 3688 & 2319 & 1587 & 1151 & 872 & 683 & 548 & 450 & 375 & 318 & 272 & 236 & 206 & 182 & 161 & 144 & 130 \\
\hline & 8 & 3657 & 2299 & 1573 & 1142 & 865 & 677 & 544 & 446 & 372 & 315 & 270 & 234 & 204 & 180 & 160 & 143 & 129 \\
\hline & 9 & 3631 & 2282 & 1562 & 1133 & 859 & 672 & 540 & 443 & 369 & 313 & 268 & 232 & 203 & 179 & 159 & 142 & 128 \\
\hline & 10 & 3608 & 2268 & 1552 & 1126 & 853 & 668 & 536 & 440 & 367 & 311 & 266 & 231 & 202 & 178 & 158 & 141 & 127 \\
\hline \multirow{8}{*}{20} & 3 & 5237 & 3292 & 2253 & 1635 & 1238 & 969 & 778 & 638 & 533 & 451 & 387 & 335 & 293 & 258 & 229 & 205 & 184 \\
\hline & 4 & 5088 & 3198 & 2189 & 1588 & 1203 & 942 & 756 & 620 & 518 & 438 & 376 & 325 & 284 & 251 & 223 & 199 & 179 \\
\hline & 5 & 4999 & 3143 & 2151 & 1561 & 1182 & 925 & 743 & 609 & 509 & 431 & 369 & 320 & 280 & 246 & 219 & 196 & 176 \\
\hline & 6 & 4937 & 3104 & 2124 & 1541 & 1167 & 914 & 734 & 602 & 502 & 425 & 364 & 316 & 276 & 243 & 216 & 193 & 174 \\
\hline & 7 & 4890 & 3074 & 2104 & 1527 & 1156 & 905 & 727 & 596 & 497 & 421 & 361 & 313 & 273 & 241 & 214 & 191 & 172 \\
\hline & 8 & 4852 & 3050 & 2087 & 1515 & 1147 & 898 & 721 & 592 & 494 & 418 & 358 & 310 & 271 & 239 & 212 & 190 & 171 \\
\hline & 9 & 4820 & 3030 & 2074 & 1505 & 1140 & 892 & 717 & 588 & 490 & 415 & 356 & 308 & 270 & 238 & 211 & 189 & 169 \\
\hline & 10 & 4793 & 3013 & 2062 & 1496 & 1133 & 887 & 712 & 584 & 488 & 413 & 354 & 307 & 268 & 236 & 210 & 187 & 168 \\
\hline \multirow{8}{*}{25} & 3 & 6478 & 4072 & 2787 & 2022 & 1532 & 1199 & 963 & 790 & 659 & 558 & 478 & 414 & 362 & 319 & 284 & 253 & 228 \\
\hline & 4 & 6316 & 3970 & 2717 & 1972 & 1493 & 1169 & 939 & 770 & 643 & 544 & 466 & 404 & 353 & 311 & 276 & 247 & 222 \\
\hline & 5 & 6217 & 3908 & 2674 & 1941 & 1470 & 1151 & 924 & 758 & 632 & 535 & 459 & 398 & 348 & 306 & 272 & 243 & 219 \\
\hline & 6 & 6146 & 3864 & 2644 & 1919 & 1453 & 1138 & 914 & 749 & 625 & 529 & 454 & 393 & 344 & 303 & 269 & 240 & 216 \\
\hline & 7 & 6092 & 3829 & 2621 & 1902 & 1440 & 1127 & 906 & 743 & 620 & 525 & 450 & 390 & 341 & 300 & 267 & 238 & 214 \\
\hline & 8 & 6047 & 3802 & 2602 & 1888 & 1430 & 1119 & 899 & 737 & 615 & 521 & 446 & 387 & 338 & 298 & 265 & 237 & 213 \\
\hline & 9 & 6010 & 3778 & 2586 & 1876 & 1421 & 1112 & 893 & 733 & 611 & 518 & 444 & 384 & 336 & 296 & 263 & 235 & 211 \\
\hline & 10 & 5978 & 3758 & 2572 & 1866 & 1414 & 1106 & 889 & 729 & 608 & 515 & 441 & 382 & 334 & 295 & 262 & 234 & 210 \\
\hline
\end{tabular}

2018); and black oats with common vetch (Cargnelutti Filho et al., 2020), the application of Smith (1938) and Hatheway (1961) methodologies has also generated subsidies for planning experiments.

It is indicated to use plots of $10 \mathrm{~m}^{2}$, due to practical feasibility in the field and the stabilization of accuracy from this size that is higher than those established for millet (Pennisetum glaucum L.), cv. comum (Burin et al., 2015, 2016) and for $C$. juncea (Facco et al., 2017) and lower than or equal to those used in the experiments with millet and showy rattlebox, along with other ground cover species, by Debiasi et al. (2016), Passos et al. (2017), Sousa et al. (2017), São Miguel et al. (2018), Scavazza et al. (2018), Ferreira et al. (2019), Pfüller et al. (2019), and Nascimento et al. (2020).

\section{Conclusions}

In experiments to evaluate the mass of fresh matter of millet and showy rattlebox, in single cultivation or in intercrop, with 5 to 25 treatments and with five repetitions, plots of $10 \mathrm{~m}^{2}$ of useful area are sufficient for differences between treatments of $9 \%$ of the overall average of the experiment to be considered significant at 0.05 probability.

\section{Acknowledgments}

To the Conselho Nacional de Desenvolvimento Científico e Tecnológico (CNPq - Processes 401045/2016-1 and 304652/2017-2), the Coordenação de Aperfeiçoamento de Pessoal de Nível Superior (CAPES) and the Fundação de 
Amparo à Pesquisa do Estado do Rio Grande do Sul (FAPERGS) for granting scholarships to the authors. To the scholarship students and volunteers for helping in data collection.

\section{Compliance with Ethical Standards}

Author contributions: Conceptualization: ACF; Data curation: ACF, JMS, DLS, SLC, BFO, LFO; Formal analysis: ACF; Funding acquisition: ACF; Investigation: ACF, JMS, DLS, SLC, BFO, LFO; Methodology: ACF; Project administration: ACF; Resources: ACF; Software: ACF; Supervision: ACF; Validation: ACF; Visualization: ACF; Writing - original draft: ACF; Writing review \& editing: ACF, JMS, DLS, SLC, BFO, LFO.

Conflict of interest: The authors declared that there are no conflicts of interest (professional or financial) that could influence the article.

Conselho Nacional de Desenvolvimento Científico e Tecnológico (CNPq - Processos 401045/2016-1 e 304652/20172), Coordenação de Aperfeiçoamento de Pessoal de Nível Superior - Brasil (CAPES) - Finance Code 001, and Fundação de Amparo à Pesquisa do Estado do Rio Grande do Sul (FAPERGS).

\section{Literature Cited}

Alvares, C.A.; Stape, J.L.; Sentelhas, P.C.; Gonçalves, J.L.M.; Sparovek, G. Köppen's climate classification map for Brazil. Meteorologische Zeitschrift, v.22, n.6, p.711-728, 2013. https:// doi.org/10.1127/0941-2948/2013/0507.

Burin, C.; Cargnelutti Filho, A.; Alves, B.M.; Toebe, M.; Kleinpaul, J.A. Plot size and number of replicates in times of sowing and cuts of millet. Revista Brasileira de Engenharia Agrícola e Ambiental, v.20, n.2, p.119-127, 2016. https://doi.org/10.1590/1807-1929/ agriambi.v20n2p119-127.

Burin, C.; Cargnelutti Filho, A.; Alves, B.M.; Toebe, M.; Kleinpaul, J.A. Neu, I.M.M. Tamanho de parcela e número de repetições na cultura do milheto em épocas de avaliação. Bragantia, v.74, n.3, p.261-269, 2015. https://dx.doi.org/10.1590/1678-4499.0465.

Cargnelutti Filho, A.; Neu, I.M.M.; Santos, G.O.; Facco, G.; Wartha, C.A.; Kleinpaul, J.A. Plot size related to numbers of treatments, repetitions, and the experimental precision in flax. Comunicata Scientiae, v.9, n.4, p.629-636, 2018. https://doi.org/10.14295/cs.v9i4.1809.

Cargnelutti Filho, A.; Souza, J.M.; Pezzini, R.V.; Neu, I.M.M.; Silveira, D.L.; Procedi, A. Optimal plot size for experiments with black oats and the common vetch. Ciência Rural, v.50, n.3, e20190123, 2020. https://doi.org/10.1590/0103-8478cr20190123.

Cargnelutti Filho, A.; Toebe, M.; Alves, B.M.; Burin, C.; Neu, I.M.M.; Facco, G. Tamanho de parcela para avaliar a massa de plantas de mucuna cinza. Comunicata Scientiae, v.5, n.2, p.196-204, 2014a. http://comunicatascientiae.com.br/comunicata/article/ view/328/245. 04 Jun. 2020.

Cargnelutti Filho, A.; Toebe, M.; Burin, C.; Casarotto, G.; Alves, B.M. Planejamentos experimentais em nabo forrageiro semeado a lanço e em linha. Bioscience Journal, v.30, n.3, p.677-686, 2014b. http://www.seer.ufu.br/index.php/biosciencejournal/article/ view/18048/13925. 04 Jun. 2020.
Debiasi, H.; Franchini, J.C.; Dias, W.P.; Ramos Junior, E.U.; Balbinot Junior, A.A. Práticas culturais na entressafra da soja para o controle de Pratylenchus brachyurus. Pesquisa Agropecuária Brasileira, v.51, n.10, p.1720-1728, 2016. https://doi. org/10.1590/s0100-204x2016001000003.

Donato, S.L.R.; Silva, J.A.; Guimarães, B.V.C.; Silva, S.O. Experimental planning for the evaluation of phenotipic descriptors in banana. Revista Brasileira de Fruticultura, v.40, n.5, p.1-13, 2018. https://doi.org/10.1590/0100-29452018962.

Facco, G.; Cargnelutti Filho, A.; Alves, B.M.; Lavezo, A.; Follmann, D.N.; Bem, C.M.; Schabarum, D.E.; Kleinpaul, J.A.; Chaves, G.G.; Silveira, D.L.; Simões, F.M.; Uliana, D.B.; Wartha, C.A. Basic experimental unit and plot sizes with the method of maximum curvature of the coefficient of variation in sunn hemp. African Journal of Agricultural Research, v.12, n.6, p.415-423, 2017. https://doi.org/10.5897/AJAR2016.11814.

Ferreira, D.F. Sisvar: a guide for its bootstrap procedures in multiple comparisons. Ciência e Agrotecnologia, v.38, n.2, p.109-112, 2014. https://doi.org/10.1590/S1413-70542014000200001.

Ferreira, N.M.; Santos, D.; Bertino, A.M.P.; Cavalcante, A.C.P.; Pereira, W.E.; Bertino, A.M.P.; Oliveira, A.P. Potential of species of green coverage in Entisol. Journal of Agricultural Science, v.11, n.11, p.263-273, 2019. https://doi.org/10.5539/jas. v11n11p263.

Guimarães, B.V.C.; Donato, S.L.R.; Aspiazú, I.; Azevedo, A.M.; Carvalho, A.J. Optimal plot size for experimental trials with Opuntia cactus pear. Acta Scientiarum. Technology, v.42, p.e42579, 2020. https://doi.org/10.4025/actascitechnol. v42i1.42579.

Hatheway, W.H. Convenient plot size. Agronomy Journal, v.53, n.4, p.279-280, 1961. https://doi.org/10.2134/ agronj1961.00021962005300040025x.

Lin, C.S.; Binns, M.R. Relative efficiency of two randomized block designs having different plot sizes and numbers of replications and of plots per block. Agronomy Journal, v.78, n.3, p.531-534, 1986. https://doi.org/10.2134/ agronj1986.00021962007800030029x.

Nascimento, D.D.; Vidal, R.L.; Pimenta, A.A.; Castro, M.G.C.; Soares, P.L.M. Crotalaria and millet as alternative controls of root-knot nematodes infecting okra. Bioscience Journal, v.36, n.3, p.713719, 2020. http://dx.doi.org/10.14393/BJ-v36n3a2020-42248.

Paranaíba, P.F.; Ferreira, D.F.; Morais, A.R. Tamanho ótimo de parcelas experimentais: proposição de métodos de estimação. Revista Brasileira de Biometria, v.27, n.2, p.255-268, 2009. http://jaguar.fcav.unesp.br/RME/fasciculos/v27/v27_n2/ Patricia.pdf. 04 Jun. 2020.

Passos, A.M.A.; Aker, A.M.; Costa, R.S.C.; Santos, F.C.; Leite, V.P.D.; Marcolan, A.L. Effect of cover crops on physico-chemical attributes of soil in a short-term experiment in the southwestern Amazon region. African Journal of Agricultural Research, v.12, n.47, p.3339-3347, 2017. https://doi.org/10.5897/ AJAR2017.12800.

Pfüller, E.E.; Santos, D.B.; Aires, R.F.; Samaniego, M.D.P.G. Aspectos fenológicos e produtividade de espécies de verão para cobertura de solo em Vacaria, RS. Investigación Agraria, v.21, n.1, p.23-30, 2019. https://doi.org/10.18004/investig. agrar.2019.junio.23-30. 
Santos, H.G.; Jacomine, P.K.T.; Anjos, L.H.C.; Oliveira, V.A.; Lumbreras, J.F.; Coelho, M.R.; Almeida, J.A.; Araújo Filho, J.C.; Oliveira, J.B.; Cunha, T.J.F. Sistema Brasileiro de Classificação de Solos. Brasília: Embrapa, 2018. 356p.

São Miguel, A.S.D.C.; Pacheco, L.P.; Souza, E.D.; Silva, C.M.R.; Carvalho, Í.C. Cover crops in the weed management in soybean culture. Planta Daninha, v.36, p.e18172534, 2018. https://doi. org/10.1590/S0100-83582018360100072.

Scavazza, A.L.; Soares, M.R.; Casagrande, J.C.; Medeiros, S.D.S.; Santi, P.H.P. Produção de fitomassa e extração de macronutrientes por plantas de cobertura cultivadas na estação seca. Nativa, v.6, n.6, p.619-624, 2018. https://doi.org/10.31413/nativa.v6i6.5609.
Smith, H.F. An empirical law describing heterogeneity in the yields of agricultural crops. Journal of Agricultural Science, v.28, n.1, p.123, 1938. https://doi.org/10.1017/S0021859600050516.

Sousa, D.C.; Medeiros, J.C.; Rosa, J.D.; Lacerda, J.J.J.; Mafra, Á.L.; Mendes, W.S. Chemical attributes of agricultural soil after the cultivation of cover crops. Australian Journal of Crop Science, v.11, n.11, p.1497-1503, 2017. https://doi.org/10.21475/ ajcs.17.11.11.pne799.

Sousa, R.P.; Silva, P.S.L.; Assis, J.P. Tamanho e forma de parcelas para experimentos com girassol. Revista Ciência Agronômica, v.47, n.4, p.683-690, 2016. http://ccarevista.ufc.br/seer/index.php/ ccarevista/article/view/4326. 04 Jun. 2020. 